\title{
Max Weber's Odyssey: The Wild West, the Frontier, and the Capitalist Spirit
}

\author{
David Norman Smith
}

Of all the classical theorists, Max Weber is the most vivid in the eyes of scholars today. Simmel is an acquired taste, Durkheim a grey eminence, Tönnies an afterthought, and even Marx- despite his worldwide renown, despite the swelling tide of biographies - is an embodied Idea, a screen for projection and debate. Only Max Weber is a living presence for contemporaries. Curiosity is sparked not only by his work but by his personality, which biographers often call "volcanic," "tormented," "Angst-ridden." Apparently, no aspect of Weber's life is beyond the pale. Topics of perennial interest include the seemingly Oedipal character of the trauma that paralyzed Weber on the eve of the twentieth century, the intimate details of his marriage to Marianne Weber, and the tenor of his friendship with Else Jaffé and her sisters. ${ }^{1}$

Scrutiny of this kind is usually reserved for literary lions. Proust, Kafka, Woolf, Mann, and others are appraised in minute personal detail, but their contemporaries among sociologists (Sombart, Tarde, Sorokin) are literary unknowns. As a signal exception to this rule, Max Weber thus figures as a kind of Wissenschaftliche Joyce, a Soziologische Auden or Dostoevsky. Whether for good or ill, Max Weber has a vibrant literary persona. ${ }^{2}$

This persona, the "Max Weber" of iconographic memory, is stereotypically German. Hence in most biographical accounts, the accent is placed on Weber's central European persona and ties - his connections to Troeltsch and Treitschke, to pan-Germanism and neo-Kantianism, to Lask and Lukács. ${ }^{3}$ His deep interest in other cultures and continents has remained relatively obscure. Even his decade-long inquiry into the "world religions" of India, China, and ancient Palestine has interested relatively few scholars (among whom comparativists of neo-Weberian outlook loom large - including, e.g., Bendix, Schluchter, and Kalberg). ${ }^{4}$ Moreover, Weber's abiding interest in the United States and Russia has begun to attract substantial attention only fairly recently. ${ }^{5}$

In what follows, my subject is just one aspect of Weber's thinking with respect to the United States in particular, namely, his view of frontier regions as new horizons for capitalism. This was not an incidental or side issue for Weber, whose famed analysis of The Protestant Ethic and the Spirit of Capitalism was only half-finished when he traveled through the United States in 1904. ${ }^{6}$ Nor is Weber's outlook on this topic immaterial for contemporary historians, many of whom now affirm quasi-Weberian views under such rubrics as "the New Western" history."

A full account of Weber's notion of the frontier would exceed the limits of a journal article, but we can highlight key points by recalling Max and Marianne Weber's trek across the territorial United States in 1904. This journey is fairly well known, thanks to several sources - Marianne's memoirs, Max's essay on “The Protestant Sects and the Spirit of Capitalism” (1906), and recent studies by Bärbel Meurer, Lawrence Scaff, Hans Rollman, and Guenther Roth. ${ }^{8}$ But the substance of what they learned on this journey has not yet been very fully integrated into the broader literature on either of them. ${ }^{9}$

Max Weber was, briefly, a wayfaring stranger in Mark Twain's America. And his account of what he saw there sheds light on themes familiar from other writers of the period - notably, that America in the gilded age was a jungle of industry and greed, of railroads and robber barons, in which, even in the realm of faith, capitalism left an indelible imprint. 


\section{| Weber's Odyssey}

Marianne and Max Weber came to the United States in 1904 with their close friend Ernst Troeltsch, at the invitation of the Harvard University psychologist Hugo Münsterberg, who had offered both of the men honoraria to speak at a session held in conjunction with the St. Louis World's Fair. Their pilgrimage to Missouri began in "Manhattan island," as Marianne wrote, and carried them to Niagara Falls, Philadelphia, Chicago and (finally) St. Louis. After the World's Fair, Max and Marianne went south. Wishing to meet Max's cousins in the Blue Ridge mountains after touring Oklahoma, New Orleans, and Washington D.C., they arrived in October in North Carolina, ${ }^{10}$ where the most picturesque episode of their odyssey took place.

In this episode we find Max and Marianne in the mountains, with Max's "Uncle Fritz" Fallenstein (who had changed his name to "Miller" when he came to the U.S. from Germany and with Fritz's children Jefferson, James, Hugh and Betty; another cousin, Frank; and many spouses and children. ${ }^{11}$ Jeff and Jim owned hillside farms "within shouting distance" of one another in the woods outside Mount Airy, ${ }^{12}$ near the Virginia border. Hugh, who was single, lived with Jim's family, and Betty lived nearby as well. Frank, a recent arrival from Germany, lived seven miles away in Red Brush.

Living in modest wooden farmhouses "with none of the comfortable expansiveness and floral decoration of German farmhouses," the Millers raised corn, wheat, tobacco, and cattle. They led "simple lives with little culture," as Marianne recalled condescendingly. After dinner, the men occupied themselves with fireside conversations. Max evidently felt quite at home as he made clear in a letter: “...we sat around the fireplace...and everybody chewed tobacco. Jeff spat well-aimed streams of brown sauce into the fire through and over the legs of those sitting in between. We were in quite good humor...” (Biography [1926] 1975: 297, 296, 298).

This sounds like a scene from Huckleberry Finn. Marianne's account of the cheerful conversations "among the corncobs outside" has a similar quality: "...I had to stay inside with the women and had only an occasional chance to pursue a burst of laughter which Max conjured up on the men's side. ... They often slapped him on the knee and called him a 'mighty jolly fellow'." (Biography [1926] 1975: 299-300)

Max found his relatives intriguing and, in some ways, typical. Lamenting the anti-Black prejudice he found on all sides, Max, in a letter cited by Marianne, called Fritz one of "the good, proud, but confused people" who accepted neo-Confederate narratives about secession and the Civil War. Fritz had "never owned a slave and was a strict abolitionist, but he always fought on the side of the slaveholders, because according to his Jefferson-Calhoun theory his state...had the formal right to secede" (Biography [1926] 1975: 296). ${ }^{13}$

The religious views of the family were also of interest. The decisive figure in this regard was Fritz's wife. Fritz was a Methodist, Max wrote, "because every day his wife made him fear the torments of hell to which he would otherwise be subjected." Jim and Betty were also pious, but "the entirely unchurchly Jeff" was a skeptic, who had been "driven from any connection with the church by the terrible severity of his mother" (Biography [1926] 1975: 296, 298). ${ }^{14}$

Seeing this rift in the family was enlightening, as Max explained in connection with a baptism he attended one "beautiful sunny day" in Brushy Fork Pond by the Mount Carmel Baptist Church ("Protestant Sects" [1906] 1946: 304).

In the open air eight people...were submerged in the icy water of the mountain brook... The preacher, dressed in a black suit, stands in the water up to his hips; one after another the candidates for baptism get into the brook, grasp his hands, and after the various vows have been spoken, ...lean backwards until their face is under water. Then they come out snorting, are 'congratulated,' and either go home dripping wet or, if they live far away, change clothes in a wooden shack. They do this even in the middle of winter, chopping a hole in the ice for this purpose. (Biography [1926] 1975: 298)

On the riverbank a revealing exchange took place: "James said that 'faith' kept them from catching cold. Jeff, who regards all this as nonsense, said that he had asked one of them, 'Didn't you feel pretty cold, Bem?' The answer: 'I thought of some pretty hot place (hell, of course), Sir, and so I didn't care for the cold water' (Biography [1926] 1975: 298). ${ }^{15}$ The baptism of another young man also yielded a telling exchange. "Look at him," Jeff said, "I told you so!" "Why did you expect that?" Max asked. "Because he wants to open a bank in [Mount Airy]," Jeff answered ("Die protestantische Sekten" [1906] 1947: 210, italics added). The point, Max realized, was that confirmation as a Baptist counted as a sign of approval from notables of the local community. The only way to win admission to the local Baptist congregation was to pass a moral screening, thus earning a reputation for probity. 
This, Jeff cynically hinted, was reason enough for an aspiring banker to be baptized. It was good for business. Piety paid a dividend.

Max found this point compelling. "In general," he concluded, "only those men had success in business who belonged to Methodist or Baptist or other sects or sect-like conventicles. When a sect member moved to a different place, or if he was a traveling salesman, he carried the certificate of his congregation with him; and thereby he found not only easy contact with sect members but, above all, he found credit everywhere" "Protestant Sects" [1906] 1946: 305). The profit motive had infiltrated the realm of faith, giving the phrase "full faith and credit" a decidedly thisworldly connotation.

\section{| Occidental Rationalism and Frontier Capitalism}

A conversation on a train in Oklahoma just a few weeks earlier had prepared Weber to grasp this point. Seated "next to a traveling salesman of 'undertaker's hardware' (iron letters for tombstones)," Max commented in passing on the persistence of an "impressively strong church-mindedness." The salesman replied, "Sir, for my part everybody may believe or not believe as he pleases; but if I saw a farmer or a businessman not belonging to any church at all, I wouldn't trust him with fifty cents. Why pay me, if he doesn't believe in anything?"16

Hence "belief," as revealed by the embrace of a churchly ethic of conviction, is a "proof" of a moral and commercial character. Only believers are credible; only the Gesinnungsethiker is creditworthy. ${ }^{17}$

Here, as elsewhere, Weber saw evidence of the prodigious transformative power of youthful capitalism. Even the innermost regions of culture and conviction now bore the fingerprints of "business interest." The same was true of the forests and fields of the once wild frontier, which Max and Marianne observed at first-hand in Oklahoma, "in an area that until recently had been reserved for the Indians. Here," Marianne reminisced,

it was still possible to observe the unarmed subjugation and absorption of an 'inferior' race by a 'superior', more intelligent one, the transformation of Indian tribal property into private property, and the conquest of the virgin forest by colonists. Weber stayed with a half-breed. He watched, listened, transformed himself into his surroundings, and thus everywhere penetrated to the heart of things. (Biography [1926] 1975: 291) $)^{18}$

Entering Oklahoma, Weber noted the "impenetrable" overgrowth of the "veritable virgin forest," the "yellow, quiet forest brooks" and serpentine rivers "in an utterly wild state, with enormous sandbanks and thick, dark greenery on their banks. ...But the virgin forest's hour has struck even here." Indian cabins marked by colorful shawls were found side by side with "quite modern wooden houses from the factory," and the forest itself was in decay: "The trees...are dying and stretching their pale, smoky fingers upward in a confused tangle... And suddenly one begins to smell petroleum; one sees the high, Eiffel Tower-like structures of the drill holes in the middle of the forest and comes to a 'town'.” (Biography [1926] 1975: 291-92)

In these boomtowns, which were so rapidly eroding the wilderness, Weber found striking evidence of the vitality of nascent capitalism. "Such a town is really a crazy thing: the camps of the workers, especially section hands working for the numerous railroads under construction, streets in a primitive state, usually doused with petroleum twice each summer to prevent dust, and...wooden churches of at least four or five denominations." Under this primitive façade, Max saw the signs of "a colossal 'boom"” -- frenzied land speculation, a flood of immigrants, a "tangle of telegraph and telephone wires. ...There is a fabulous bustle here, and I cannot help but find tremendous fascination in it, despite the stench of petroleum and the fumes, the spitting 'Yankees,' and the racket of the numerous trains" (Biography [1926]: 292-93).

Although surprised at being accosted by eager entrepreneurs (“two 'real-estate men,' an asphalt man, and two traveling salesman"), Max found the townsfolk likable. All officials have received me in their shirt sleeves, of course, and together we put our legs on the windowsill... In the conversations...the courtesy lies in the tone and the bearing, and the humor is nothing short of delicious. Too bad: in a year this place will look like Oklahoma [City], that is, like any other American city. With almost lightning speed everything that stands in the way of capitalistic culture is being crushed. (Biography [1926] 1975: 293) 


\title{
Journalism in Oklahoma
}

Not every vestige of the frontier had vanished, however. An episode in Guthrie, Oklahoma (as reported in The Daily Oklahoman on September 28, 1904), shows that Mark Twain's America was still alive and kicking. "WOULDN'T STAY”, ran the headline. "A GERMAN PROFESSOR'S VISIT AT GUTHRIE WAS SUDDENLY TERMINATED. SAYS GREER NO 'SHENTLEMAN.' Had Intended Calling On the Editor But Heard He Used a Gun on Another Editor, and That Settled It."19

The ensuing article explains, breathlessly, that "a man of prominence, who registered as Prof. Von Webber of Heidelberg University, Germany," had arrived in Guthrie on the Santa Fe railway the day before, carrying "quite an amount of luggage. ...He claimed to hold down the chair of economics at Heidelberg and to be traveling through the United States to get posted on conditions here in his line." Upon arrival at the Hotel Royal, the Professor told the proprietor, Fred van Dyne, that he would stay a week before proceeding to Muskogee. But not long after, "Von Webber" raced downstairs to report that he would leave immediately. In explanation, he reportedly said: "I have a letter of introduction to a newspaper man here, the editor of the State Capital, but since I came to the city I see by the papers that he carries a gun and that he drew a gun on another editor. I can not see how a man who carries a gun can be a 'shentlemans' and, therefore, I will not meet him, but will go at once to Muskogee.' When all efforts to persuade him to stay failed, he departed post haste.

This episode appears to have occasioned some astonishment in the offices of The Daily Oklahoman. "Fred Van Dyne...vouches for the truth" of this report, the newspaper explained. Evidently, the Heidelberg Professor's decision was hard to fathom..$^{20}$

Mark Twain would have understood. Indeed, The Daily Oklahoman story could easily have been drawn from a misadventure Twain said befell him in Tennessee some years before. "I was told by the physician that a Southern climate would improve my health," Twain wrote ([1869] 1985: 29-32), "and so I went down to Tennessee, and got a berth on the Morning Glory and Johnson County War-Whoop as associate editor." Instructed to write an overview of the local press, Twain soon found that his style was too mild. The chief editor scowled.

\begin{abstract}
Presently he sprang up and said: 'Thunder and lighting! Do you suppose I am going to speak of these cattle that way? Do you suppose my subscribers are going to stand such gruel as that? Give me the pen!' I never saw a pen scrape and scratch its way so viciously, or plow through another man's verbs and adjectives so relentlessly. While he was in the midst of his work, somebody shot at him through the open window, and marred the symmetry of my ear. 'Ah', said he, 'that is that scoundrel Smith, of the Moral Volcano. He was due yesterday.' And he snatched a navy revolver from his belt and fired. Smith dropped, shot in the thigh. The shot spoiled Smith's aim, who was taking a second chance, and he crippled a stranger. It was me. Merely a finger shot off.
\end{abstract}

Poor Twain! Before the day is done, he becomes the unintended victim of a whip, flying debris, a fall from a window, a virtual grenade, and myriad stray bullets. All of these injuries are suffered at the hands of incensed rival editors, among them (in the words of the chief editor) "that ass, Blossom, of the Higginsville Thunderbolt and Battle Cry of Freedom," "the inveterate liars of the Semi-Weekly Earthquake," "the besotted blackguard of the Mud Springs Morning Howl," and (memorably) Colonel Tecumseh. "The Colonel appeared in the door...with a dragoon revolver in his hand. He said, "Sir, have I the honor of addressing the poltroon who edits this mangy sheet?" "You have. Be seated, sir. Be careful of that chair, one of its legs is gone. I believe I have the honor of addressing the putrid liar, Colonel Blatherskite Tecumseh?" "Right, sir. I have a little account to settle with you. If you are at leisure we will begin." "I have an article on the 'Encouraging Progress of Moral and Intellectual Development in America' to finish, but there is no hurry. Begin."

In the melée that ensues, the unfortunate Twain is shot in the arm and knuckle. "I then said, I believed I would go out and take a walk, as this was a private matter, and I had a delicacy about participating in it further. But both gentlemen begged me to keep my seat, and assured me that I was not in the way. They then talked about the elections and the crops while they reloaded, and I fell to tying up my wounds." When, at last, the Colonel was fatally wounded, "[he] remarked, with fine humor, that he would have to say good morning now, as he had business uptown. He then inquired the way to the undertaker's and left." ${ }^{21}$ 


\section{"The Boiling Heat of Modern Capitalistic Culture"}

From Mark Twain, as from Max Weber, we learn that the "progress of moral and intellectual development in America" does not take place with pristine purity, hermetically sealed from everything extra-rational. Unlike, e.g., the "rational actor" theorists of the New Resource Economics, who advance "a purely economic theory of Western society" (Brady \& Noll, 1994), Twain and Weber were well aware that the "rationalization" of Gilded Age society did not require perfect utility-maximizing rationality. And capitalism, too, is often decisively irrational, harnessing or replicating the aggressive rivalries of what Richard Slotkin aptly calls the Gunfighter Nation. ${ }^{22}$ Many people fall by the wayside in what Max Weber, speaking in St. Louis, called "the strong blast of modern capitalistic competition" ([1904] 1946: 366). And capitalism, of course, is strictly non-rational in substantive terms. Illustrating this point in connection with Benjamin Franklin, Weber wrote, just before visiting the U.S., that in Franklin's capitalist ethic "Man is dominated by the making of money, by acquisition as the ultimate purpose of his life. Economic acquisition is no longer subordinated to man as the means for the satisfaction of his material needs." On "this reversal of what we should call the natural relationship," Weber makes two points: it is, to start with, extremely "irrational from a naïve point of view," yet nonetheless "as definitely a leading principle of capitalism as it is foreign to all peoples not under capitalistic influence" ([1904-05] 1976: 53).

Weber came to St. Louis in 1904 to speak about capitalism and rural society. What he said there remains relevant. In fact, the position Weber took on that occasion is a surprising blend of old and new trends in Western historiography. For the past decade, "New Western Historians" have been sharply at odds with partisans of the old orthodoxy, whose starting point has long been the "Frontier Thesis" of Frederick Jackson Turner (cf. Faragher 1994: 225f. and Limerick et al. 1991, passim). Weber, speaking just a decade after Turner gave his famous lecture on "The Significance of the Frontier in American History" ([1893] 1994), echoed Turner's logic in some respects while anticipating his "New Western" critics in others. ${ }^{23}$

Turner was a celebrant of the rough-hewn frontier democracy which, he believed, had triumphed when Andrew Jackson won the presidency and, several years later, abolished the national bank. ${ }^{24}$ There was, Turner said, a frontier dynamic that powerfully spurred democracy, individualism, and a new invigorated national identity. "Western democracy was no theorist's dream," he said. "It came, stark and strong and full of life, from the American forest" (1906: 69). And the frontier "ideal," he added, was faith in "the worth and possibilities of the common man, ...belief in the right of every man to rise to the full measure of his own nature, under conditions of social mobility" (68-9). Notwithstanding internal differences of various types, the Western frontier had "a fundamental unity in its social structure and its democratic ideals" (72). And the west was a safety valve for the stratified east, an open door for urban workers to find freedom on the land, thus defusing class tensions.

This Arcadian history, however, was now past. The supply of free land was exhausted, and hence, as Turner concluded his original essay, "the frontier has gone, and with its going has closed the first period of American history ([1893] 1994: 60).

Turner's vision reigned almost unchallenged until his death in 1932 and remained orthodox even after many serious criticisms had been leveled and sustained. But in the past generation, this orthodoxy has been ever more comprehensively assailed. Paul Wallace Gates, in 1957, set the stage for many later critics when he charged Turner with glossing over frontier relations between capital and labor ([1957] 1968: 114f.).

More recently the failure of the Turnerian perspective to account for gender and race divisions has been eloquently demonstrated (Limerick 1987, Riley 1984), while others (Robbins 1994, Worster 1985) have deepened the critique of frontier capitalism (and rationalism). All this, in turn, has provoked strong resistance, not least, as William Robbins observes, from old-guard historians unfriendly to those who "invoke the dreaded ' $\mathrm{C}$ ' word - capitalism - in discussing the West and its larger world" (1991: 188).

Max Weber did not hesitate to apply the "C" word to the frontier West. Yet his views on the frontier were not strictly or merely anti-Turnerian. Indeed, he took a position that is both Turnerian and "New Western." This is partly because Turner's views have been misconstrued.

Although his less critical and discerning disciples have shied away from the notion of capitalism, Turner himself stressed the passing of the earlier, more democratic West, which was giving way, he said, to a new West marked by "the manufacturing organization with city and factory" ([1893] 1994: 38). Just one year before Weber lectured in St. Louis, Turner said that "we find ourselves at the present time in an era of such profound economic and social transformation as to raise the question of the effect of these changes upon the democratic institutions of the United 
States." And he listed four new developments, which, "taken together...constitute a revolution": "the exhaustion of the supply of free land," the new expansionism of American foreign policy, the eruption of populism, and "such a [colossal] concentration of capital in the control of fundamental industries as to make a new epoch in the economic development of the United States" ([1903] 1994: 79). ${ }^{26}$

In many ways, Turner's views were vague and romantic, but in these particulars, at least, they do not clash with Max Weber's outlook. Weber, too, stresses the openness of the class system in the formative periods of United States history, which he too credits to the presence of the "immense territory" along the frontier. In Germany, where capitalism arose amid a welter of hostile forces, the path of "bourgeois liberalism" was blocked by forces new and old, by socialist workers as well as by Junker aristocrats. ${ }^{27}$ In the United States, in contrast, the working class was largely neutralized as an anti-bourgeois force by an amalgam of factors, including low population density, the relatively high price of labor-power, and opportunities on the ever-shifting Western frontier. Hence, in the Civil War and after, during the contest of strength between the bourgeois North and the Southern "planters' aristocracy," there was little working-class self-assertion. The result was the "destruction" of the planters' aristocracy, and the victory of bourgeois democracy in a form unmarked by the "peculiar authoritarian stamp" of European capitalism ([1904] 1946: 385, 372, 369).

This analysis takes the frontier thesis as a partial explanation, not simply of "democracy"in the United State but of the specifically bourgeois character of democracy after the Civil War. It was, Weber held, the uncharacteristic weakness and even absence of "adversaries of bourgeois capitalism" that made it relatively easy for the ascendant capitalist class to forge a liberal regime ([1904] 1946: 369). Hence a quasi-Turnerian perspective was, for Weber, a source of clarifying insight into American capitalism, not a barrier to such insight.

Weber also emphasizes, as Turner had, that the day of the frontier is passed. Indeed, he prophesies that the closing of the frontier marks "the last time, as long as the history of mankind shall last, that such conditions for a free and great development will be given," since "the areas of free soil are now vanishing everywhere in the world" ([1904] 1946: 385). Class polarities within U.S. capitalism, meanwhile, will grow more fixed and antagonistic: "if new districts for settlement are no longer available, and if the workingman is conscious of being forced to remain inevitably a proletarian as long as he lives," then "the disciplined masses of workingmen created by capitalism" will revert, Weber predicts, to their "natural" impulse, "to unite in a class party." This "is bound to come about sooner or later," and indeed may be visible on the horizon already ([1904] 1946: 372). ${ }^{28}$ Rural conflicts, meanwhile, will also grow more acute as "capital...begins to monopolize the land to a great extent" and as the "absolute economic individualism" of small farmers falls beneath the scythe of bourgeois competition ([1904] 1946: 383, 364).

From this vantage point, in other words, the class conflicts of the Gilded Age could not be grasped apart from the now-receding influence of the frontier west. This is the converse, and implicit corollary, of the claim by New Western Historians that the western frontier cannot be grasped apart from capitalism. And this, too, was perceived by Max Weber, who anticipates Worster, among others, when he warns that "the boiling heat of modern capitalistic culture is connected with heedless consumption of natural resources, for which there are no substitutes."29 ([1904] 1946: 366)

\section{The Next Frontier}

As the frontier recedes into memory, the environment is also imperiled. It was in this spirit, shortly after his return to Germany, that Weber penned the following memorable lines on the "tremendous cosmos of the modern economic order," which expands, he says, to fill every geographic and ecological niche, and which rules us morally as well as economically: "This order is now bound to technical and economic conditions of machine production that... determine the lives of all the individuals who are born into this mechanism, not only those directly concerned with economic acquisition, with irresistible force. Perhaps it will so determine them until the last ton of fossilized coal is burnt” ([1904-05] 1976: 181).

Thus does capital "rationalize" the world. The danger, Weber implies, is that this heedless rationalism may yet be our undoing. Irrationality is not restricted to capital's frontier. It is, rather, the paradoxical truth of capitalism, the underside of the instrumental, calculating, profit-driven "rationality" which turns even ordinary means of production - coal, oil, fertilizers - into means of destruction. But capital does also produce a working-class, as Weber stressed. That class, offering its labor-power for sale in every corner of today's world, remains riveted to capital by ties both 
economic and psychic. Whether workers, in all their endless varieties, will always see capitalism as "irresistible" whether they will allow states and mega-corporations to burn through every last ton of fossilized fuel - remains to be seen. However, one thing is certain: the vanished frontiers of Max Weber's day can no longer serve as safety valves for the displaced and discontented. Capitalism is still a wild west - a realm where, as Marx said, "one capitalist always kills many"30 - and it is still very much what Weber called it, "the most fateful force" in modern society ([1904-05] 1976: 17). But today that force can neither be evaded nor held at bay. There is no refuge beyond the reach of capital. The next frontier is social, a choice - whether to allow profit-hungry capitalism to run its increasingly toxic course or to find a sustainable alternative. The urgency of that choice is becoming clearer by the day.

\section{Endnotes}

1. One major recent entrant in this genre is also among the most lurid: Max Weber: A Biography by Radkau (2009). See also the older study by Mitzman (1969). For level-headed correctives, see, e.g., Käsler (1988); Kivisto \& Swatos, Jr. (1988), and my own "Charisma Disenchanted" (2013). On Weber's links to Else Jaffé and her sisters, see the insightful Martin Green (1974).

2. On Weber and Mann, see Harvey Goldman (1993 \& 1989). On Weber and Lawrence, see again Green (1974).

3. See, e.g., the anthology on Weber's contemporaries edited by Wolfgang Mommsen and Jürgen Osterhammel (1987). Curiously, nearly every figure discussed in this massive volume is European, despite Weber's wellknown interest in non-European contemporaries such as William James, Booker T. Washington, and Thorstein Veblen, among others.

4. See Bendix (1962); Schluchter (1996); and Kalberg (1994). See also my "Charisma and the Spirit of Capitalism" (2014), which discusses Weber's account of Confucianism and Taoism. And there are, of course, many specialized monographs as well. A good running overview of the specialist literature - on this and all subjects Weberian -- is provided by the journal Max Weber Studies (2000-). See also Alan Sica, Max Weber: A Comprehensive Bibliography (2004).

5. On Weber and the United States, see Erdelyi (1992), Diggins (1996), and the essential sources cited in $n$. 8, below. Future discussions of Weber and Russia, meanwhile, will rise on the foundation of the Englishand German-language editions of his writings on the Russian revolutions (1995, 1989, 1984).

6. The Protestant Ethic was originally a two-part essay in the journal that Weber edited with Werner Sombart and Edgar Jaffé, Archiv für Sozialwissenschaft und Sozialpolitik. For a superb translation of that original two-part essay -- the first part of which appeared before Weber went to the U.S. - see Weber ([1904-05] 2002), translated and edited by Peter Baehr and Gordon C. Wells. This edition also includes Weber's indispensable replies to Felix Rachfall and others in which he adds extensive clarifying detail to his account of the spirit of capitalism, which he now sharply contrasts to the spirit of plutocracy. For an overall perspective on the wider history and significance of The Protestant Ehic, see Peter Ghosh (2014).

7. On this, see Robbins (1994, 1991). Donald Worster indirectly connects to Weber (through Karl Wittfogel and Max Horkheimer) in his outstanding study, Rivers of Empire (1985: 23-24, 347 n. 8). Also notable in this respect is Richard Slotkin, whose trilogy on the Frontier Myth (1992, 1975, 1973) is strikingly Weberian in spirit.

8. On Rollman (1993), see below. Roth's many contributions include his massive account of the Weber family's far-flung Anglo-German (and Belgian, Argentinian and U.S.) connections, Max Webers deutsch-englische Familien geschichte 1800- 1950 (2001). Meurer's massive recent biography of Marianne Weber (2010) includes a brief account of the U.S. sojourn from Marianne's standpoint and material on other aspects of her connections to the United States. And I thank Larry Scaff for sharing drafts with Bob Antonio and me of his invaluable paper, "Remnants of Romanticism: Max Weber in Oklahoma and Indian Territory," which ultimately appeared in Swatos \& Kaelber (2005, 77-110). It was from Scaff, too, that we first learned about Weber's encounter with the newspaper editor recounted below. And Scaff's 2011 monograph on Weber's travel in the United States is now the indispensable standard work on this subject.

9. There are two primary sources on this expedition: Marianne's account, Max Weber: A Biography ([1926] 1975); and Max's 1906 essay "The Protestant Sects and the Spirit of Capitalism," available in Hans H. Gerth and C. Wright Mills (1946). Henceforth these sources will be cited as Biography and "Protestant Sects" respectively. Another key source is Rollman's essay in Roth \& Lehmann (1993), which drew upon unpublished papers in Troeltsch's archives to highlight the visits to New York, Chicago and St. Louis. Also invaluable is "Max Weber's Visit to North Carolina” by Larry G. Keeter (1981), which reports 1976 interviews with Max's surviving North Carolina relatives, Maggie Fallenstein and Annie Miller Booker. Relatively little 
English-language scholarship has been devoted to Marianne Weber, but, for a recent discussion, see Stacey Smith (2019). It is surprising how little overall influence the Protestant Sects essay ([1906] 1946) has exerted, even though this is one of the central loci of Weber's discussion of "charisma" and "charismatic authority" (most notably in the version of this essay that Weber revised for publication in what turned out to be his posthumous volume on the economic ethics of the world religions). The phrase "charisma of the disciples" had appeared a year earlier in the concluding chapter of The Protestant Ethic and the Spirit of Capitalism, ([19041905] 1976), but it was not until the Protestant Sects essay that Weber paused to elaborate this concept -which he borrowed from Rudolf Sohm's exegesis of the Pauline meaning of the term (see Smith, 1998). In the English-speaking countries, the neglect of this essay may be due, in part, to the fact that it was published not, as Weber intended, as an epilogue to The Protestant Ethic, but as a stand-alone essay in an anthology.

10. Diggins (1996) shows, with a map, that Tocqueville's famous journey through the U.S. took a similar route.

11. Max's mother, Helene, was the daughter of Friedrich and Emilie Fallenstein. Emilie, who was descended from Huguenots named Souchay, was Friedrich Fallenstein's second wife. His first wife, Betty, had four children -one of whom (Fritz Fallenstein) emigrated to America, where he changed his name to "Francis Miller." It was to visit "Uncle Fritz" Miller and his extended family that Max and Marianne came to North Carolina. Another cousin, Frank, the son of Fritz's brother Friedrich, had recently left Germany to join the Millers; he lived in a neighboring community. One of Max's cousins, probably Frank, was a miner to start with but later the "owner of a law office and associated with a smart Irishman for whom he did the work; he, at any rate, was on his way toward becoming a notable" (Biography [1926] 1975: 297). Fritz's three sons were poor Blue Mountain farmers; Jeff and Jim owned farms, and their unmarried brother Hugh lived with Jim and his family. Betty, a daughter, is mentioned only in passing. The other relatives are not named at all.

12. In the original text of the Protestant Sects essay ([1906] 1946: 304), Weber refers to "M. [the county seat]"; from Marianne's memoirs, it seems clear that this is Mount Airy, North Carolina. Keeter (1981) points out, however, that Mount Airy was never a county seat.

13. For analysis of the contemporary relevance, and persistence, of neo-Confederate narratives of this kind, see my forthcoming paper with Eric Hanley, "Nativism, Populism, and the White Working Class" (Critical Sociology, 2019).

14. With the exception of Jeff Miller's family, Max's cousins attended the Zion Methodist Church in Mount Airy; see Keeter (1981: 111).

15. The account of this dialogue in the Protestant Sects essay varies slightly: "One of my relatives commented that 'faith' provides unfailing protection against sneezes. Another relative stood beside me and, being unchurchly in accordance with German traditions, he looked on, spitting disdainfully over his shoulder. He spoke to one of those baptised, 'Hello, Bill, wasn't the water pretty cool?' and received the very earnest reply, 'Jeff, I thought of some pretty hot place (Hell!) and so I didn't mind the cool water"' A number of points about this passage deserve attention. Both lines of dialogue, in the German original, appear not in the main text but in footnotes; Gerth and Mills silently added these notes to the main text. They also added an ungrammatical construction ("Another relative...he") and twisted the translation in two ways: rendering "I didn't care for the water" (which appears in English in the German text) as "I didn't mind the cold water" -- and rendering "Halloh, Bill" as "Hello, Bill" ("Die protestantische Sekten" [1906] 1947: 210, fns. $1 \& 2$ ). Note also that the name of the baptized man varies from one text to the other: Bill vs. Bem. Keeter's informants reported that Bill is the correct name here, since the baptized man was Bill Phillips, the son of Joe Phillips, who owned the Brushy Fork Pond where the baptism was held. It seems likely that Marianne transcribed Weber's handwriting inaccurately in this case.

16. The salesman's reasoning here is, plainly, closely related to the logic of "civil religion," á la Bellah (1967).

17. In his famous lecture "Politics as a Vocation" ([1919] 1946), Weber opposes "Gesinnungsethik" -- the "conviction ethic" of utopians and moral absolutists -- to the worldly "ethic of responsibility" (Verantwortungsethik).

18. The romanticism of this character sketch mirrors, in spirit at least, the tales of "Old Shatterhand" by the enormously popular German novelist Karl May (especially Winnetou). In substance, however, the most notable point is that much of what Max and Marianne wrote about the treatment of Indians in the United States was sharply critical, and that Max was prepared to use the Archiv as a forum for criticism of federal policy in this sphere. "I think my host, the Cherokee, will attack the latest Indian policy of the United States in the Archiv," Max wrote in a letter. Later, Marianne recalled, "[Max's] eyes sparkled when he spoke about [this]." (Biography [1926] 1975: 294). At the same time, though, Marianne weakens her credibility as a Cherokee sympathizer when, apparently without irony, she refers to the white settlers as members of a "more intelligent" "race."

19. My thanks to Steve Kalberg and Bob Antonio for sharing this article with me.

20. Hans Rollman (1993: 380) reports that this story was picked up by many American newspapers, including the St. Louis Post Dispatch, which ran this headline: “'GUN PLAY' SCARED SAVANT. GERMAN PROFESSOR LEAVES OKLAHOMA CITY INSTANTLY WHEN EDITORS DROP WORDS FOR WEAPONS." Rollman reports that, in 
the incident in question, Oklahoma State Capitol editor Frank Greer pulled a gun on John Golobie, the editor of the Oklahoma State Register.

21. Twain had an equally jaundiced view of German journalism. Speaking about a visit to Max Weber's Heidelberg, Twain expressed amazement about the wonders of journalistic prose in Germany: "An average sentence, in a German newspaper, is a sublime and impressive curiosity; it occupies a quarter of a column; it contains all the ten parts of speech -- not in a regular order, but mixed; it is built mainly of compound words constructed by the writer on the spot, and not to be found in any dictionary -- six or seven words compacted into one, without joint or seam -- that is, without hyphens; it treats of fourteen or fifteen different subjects, each enclosed in a parenthesis of its own"; etc. ("The Awful German Language" ([1880] 1985: 441)

22. This is the title of Vol. 3 (1992) of Slotkin's great cultural triptych of American frontier mythology.

23. Weber's parallel with Turner has been noted by John Patrick Diggins (1996: 31).

24. This was an early version of the Jacksonian myth later popularized by Arthur Schlesinger. The truth of the matter -- that Jackson was originally a representative of Tennessee banking interests, who broke the National Bank to shift the balance of financial power from Chestnut Street in Philadelphia to Wall Street in New York, at the behest of New Yorker Martin Van Buren, Jackson's vice-president -- is beautifully limned by Bray Hammond ([1957] 1991).

25. See Robbins (1994: 202, n. 30) for a brief list of others who "see capitalism in its broadest form as an integral force in western American history." Meanwhile, Worster expressly adopts Max Horkheimer's critique of instrumental reason as one of the pillars of his analysis of capitalism on the western frontier. Though this approach has merits, it also serves as a rationale for the anachronistic claim that the old West, far from being "wild" and free, was a precursor of the "totally administered," "one-dimensional" society analyzed in the mid-twentieth century by Adorno and Marcuse as well as Horkheimer. In this instance, the corrective to the Frontier Myth seems nearly as one-sided as the myth itself.
26. "The iron, the coal, and the cattle of the country have all fallen under the domination of a few great corporation with allied interests, and by the rapid combination of the important railroad systems and steamship lines, in concert with these same forces, even the breadstuffs and the manufactures of the of the nation are to some degree controlled in a similar way. This is largely the work of the last decade." (Ibid., 79) Many historians have ignored this aspect of Turner's thinking, and even Donald Worster, who calls special attention to Turner's views on capital and capitalists, adds that Turner "strangely assumed that his American democracy would be unaffected" by the fundamental changes resulting from capitalization of the West (1985: 12).

27. This failure was sealed in 1878 when Bismarck allied himself with the Prussian aristocracy, thereby jilting his former allies in the bourgeois National Liberal Party (of which Max Weber Sr. was a leading member). The younger Max Weber regarded this as a decisive turning point in German history, the juncture at which the spirit of capitalism was stifled by imperial bureaucracy and Junker aristocracy. Even in the Weimar Republic, when liberalism briefly reigned, the carrier of this liberalism was the socialist SPD, not a bourgeois party; and in the polar night of icy darkness that ensued when Weimar liberalism was defeated by Hitlerian forces, the regime that came to power was, plainly, neither bourgeois nor liberal. Hence German capitalism was not destined to assume a "normal" bourgeois political form until after the end of the Second World War.

28. This "labor-safety-valve" thesis has been one of the most controversial elements of Turner's doctrine. See, e.g., the three essays collected by Richard Hofstadter and Seymour Martin Lipset (1968: 172-224), in which Shannon offers a "post-mortem" on the theory, Simler offers a qualified dissent, and Murphy \& Zellner challenge Shannon directly.

29. It is hence "difficult," he concludes, "to determine how long the present supply of coal and ore will last."

30. Marx, Capital, Vol. 1 ([1867] 1976: 928).

\section{References}

Anderson, Terry L. and Peter J. Hill (eds.) (1994) Politica Economy of the American West. Lanham, MD: Rowman \& Littlefield.
Bellah, Robert (1967) "Civil Religion in America," in the Journal of the American Academy of Arts and Sciences, 96 (1).

Bendix, Reinhard (1962) Max Weber: An Intellectual Portrait. Garden City, NY: Anchor. 
Brady, David W. and Roger G. Noll (1994) "Public Policy and the Admission of the Western States," in Terry L. Anderson and Peter J. Hill (eds.) Political Economy of the American West.

Cmiel, Kenneth (1990) Democratic Eloquence: The Fight over Popular Speech in Nineteenth-Century America. Berkeley: University of California.

Diggins, John Patrick (1996) Max Weber: Politics and the Spirit of Tragedy. New York: Basic Books.

Erdelyi, Agnes (1992) Max Weber in Amerika. Munich: Passagen.

Farager, John Mack (1994) "Afterword," in J. M. Farager (ed.) Rereading Frederick Jackson Turner. New York: Henry Holt.

Gates, Paul Wallace ([1957] 1968) "Frontier Estate Builders and Farm Laborers," in Richard Hofstadter and Seymour Martin Lipset (eds.) Turner and the Sociology of the Frontier.

Gerth, Hans H. and C. Wright Mills (eds.) ( 1946) From Max Weber. New York: Oxford.

Ghosh, Peter (2014) Max Weber and The Protestant Ethic: Twin Histories. New York: Oxford.

Goldman, Harvey (1989) Max Weber and Thomas Mann. Berkeley: University of California.

(1993) Politics, Death, and the Devil. Berkeley: University of California.

Green, Martin (1974) The von Richthofen Sisters. New York: Basic.

Hammond, Bray ([1957] 1991) Banks and Politics in America: From the Revolution to the Civil War. Princeton: Princeton University.

Hofstadter, Richard and Seymour Martin Lipset (1968) Turner and the Sociology of the Frontier. New York: Basic Books.

Käsler, Dirk (1988) Max Weber: An Introduction to His Life and Work, translated by Philippa Hurd. Chicago: University of Chicago Press. Cambridge: Polity Press.

Kalberg, Stephen (1994) Max Weber's Comparative-Historical Sociology. Chicago: The University of Chicago.

Keeter, Larry G. (1981) “Max Weber's Visit to North Carolina” in Lournal of the History of Sociology, 3 (2), Spring.

Kivisto, Peter and William H. Swatos, Jr. (1988) Max Weber: A Bio-Bibliography. New York, Westport, and London: Greenwood.

Lehmann, Hartmut and Guenther Roth (eds.) (1993) Weber's Protestant Ethic: Origins, Evidence, Contexts. New York: Cambridge University Press.

Limerick, Patricia Nelson (1987) The Legacy of Conquest: The Unbroken Past of the American West. New York: W. W. Norton.
Limerick, Patricia, Clyde A. Milner II and Charles E. Rankin (eds.) (1991) Trails: Toward a New Western History. Lawrence, KS: University of Kansas.

Marx, Karl ([1867] 1976) Capital, Vol. 1, edited by Ernest Mandel and translated by Ben Fowkes. London: Penguin Books in association with New Left Review.

Max Weber Studies (2000-), ed. Sam Whimster et al. (http:// www.maxweberstudies.org/search.htm).

Mitzman, Arthur (1969) The Iron Cage. New York: Alfred Knopf.

Mommsen, Wolfgang and Jürgen Osterhammel (eds) (1987) Max Weber and His Contemporaries. London: Unwin Hyman.

Radkau, Joachim (2009). Max Weber: A Biography, translated by Patrick Camiller. Cambridge \& Malden, MA: Polity.

Riley, Glenda (1984) Women and Indians on the Frontier. Albuquerque: University of New Mexico.

Robbins, William G. (1991) "Laying Siege to Western History: The Emergence of New Paradigms," in Patricia Limerick, Clyde Milner and Charles Rankin (eds.) Trails: Toward a New Western History.

Robbins, William G. (1994) Colony and Empire: The Capitalist Transformation of the American West. Lawrence, KS: University of Kansas.

Rollman, Hans (1993) “'Meet Me in St. Louis': Troeltsch and Weber in America," in Hartmut Lehmann and Guenther Roth (eds.) Weber's Protestant Ethic.

Roth, Guenther (2001) Max Webers deutsch-englische Familien geschichte 1800-1950 (Tübingen: Mohr Siebeck).

Scaff, Lawrence A. (2005) "Remnants of Romanticism: Max Weber in Oklahoma and Indian Territory," in William Swatos \& Lutz Kaelber (eds), The Protestant Ethic Turns 100, pp. 77-110.

-.---.---.-- (2011) Max Weber in America. Princeton, NJ: Princeton University Press.

Schluchter, Wolfgang (1996) Paradoxes of Modernity: Culture and Conduct in the Theory of Max Weber, translated by Neil Solomon. Stanford, CA: Stanford University Press.

Sica, Alan (2004) Max Weber: A Comprehensive Bibliography. New Brunswick, NJ: Transaction.

Slotkin, Richard (1973) Regeneration Through Violence: The Mythology of the American Frontier, 1600-1860. New York: Atheneum.

(1985) The Fatal Environment: The Myth of the Frontier in Twentieth-Century America. New York: Atheneum.

- (1992) Gunfighter Nation: The Myth of the Frontier in The Age of Industrialization, 1800-1890. New York: Atheneum. 
Smith, David Norman (1998) "Faith, Reason, and Charisma: Rudolf Sohm, Max Weber, and the Theology of Grace." Pp. 32-60 in Sociological Inquiry, 68:1 (February 1998).

(2013) "Charisma Disenchanted: Max Weber and His Critics," in Current Perspectives in Social Theory, 31.

- (2016) "Charisma and the Spirit of Capitalism," in The Anthem Companion to Max Weber, edited by Alan Sica. London, New York, Delhi: Anthem Press.

Smith, David Norman and Eric Hanley (2019) "Nativism, Populism, and the White Working Class" (Critical Sociology, forthcoming).

Smith, Stacey L (2019) "Marianne Weber and the March for Our Lives Movement," in Forgotten Founders and Other Neglected Social Theorists, edited by Christopher T. Conner, Nicholas M. Baxter, and David R. Dickens. Lanham, Boulder, New York and London: Lexington Books.

Swatos, William \& Lutz Kaelber (eds) (2005) The Protestant Ethic Turns 100: Essays on the Centenary of the Weber Thesis. Boulder, CO: Paradigm Publishers.

Turner, Frederick Jackson ([1893] 1994) "The Significance of the Frontier in American History," in J. M. Farager (ed.) Rereading Frederick Jackson Turner.

Turner, Frederick Jackson ([1903] 1994) "Contributions of the West to American Democracy," in J. M. Farager (ed.) Rereading Frederick Jackson Turner.

Turner, Frederick Jackson (1906) The Rise of the New West, 18191829. New York: Harper \& Brothers.

Twain, Mark ([1869] 1985) "Journalism in Tennessee," in Charles Neider (ed.) The Complete Short Stories of Mark Twain. Garden City, NY: Doubleday.

([1880] 1985) "The Awful German Language" in Charles Neider (ed.) The Complete Humorous Sketches and Tales of Mark Twain. Garden City, NY: Doubleday.

Weber, Marianne ([1926] 1975) Max Weber: A Biography, translated by Harry Zohn. New York and London: John Wiley and Sons.
Weber, Max ([1904-1905] 1976) The Protestant Ethic and the Spirit of Capitalism, translated by Talcott Parsons. London: Allen and Unwin.

([1904-1905] 2002) The Protestant Ethic and the "Spirit" of Capitalism and Other Writings, translated by Peter Baehr and Gordon C. Wells. New York: Penguin.

([1904] 1946) "Capitalism and Rural Society in Germany," in Hans H. Gerth and C. Wright Mills (eds.) From Max Weber.

([1906] 1946) "The Protestant Sects and the Spirit of Capitalism," in Hans H. Gerth and C. Wright Mills (eds.) From Max Weber.

- ([1906] 1947) "Die protestantische Sekten und der Geist des Kapitalismus," in Max Weber, Gesammelte Aufsätze zur Religionssoziologie.

- ([1919] 1946) "Politics as a Vocation," in Hans H. Gerth and C. Wright Mills (eds.) From Max Weber. First published as "Politik als Beruf" in Max Weber, Geistige Arbeit als Beruf: Vier Vortrage vor dem Freistudentischen Bund. Munich and Leipzig: Duncker and Humblot.

([1920] 1947) Gesammelte Aufsätze zur Religionssoziologie, Bd. 1. Tübingen: J. C. B. Mohr.

([1914-1918] 1984) Zur Politik im Weltkrieg, edited by Wolfgang Mommsen with Gangolf Hübinger. Tübingen: J. C. B. Mohr.

([1905-1912] 1989) Zur Russischen Revolution von 1905, edited by Wolfgang Mommsen with Dittmar Dahlman. Tübingen: J. C. B. Mohr.

(1995) The Russian Revolutions, translated by Peter Baehr and Gordon C. Wells. Ithaca, NY: Cornell University.

Worster, Donald (1985) Rivers of Empire: Water, Aridity, and the Growth of the American West. New York: Oxford University. 
